\title{
BY LAWS.
}

I.

To become a member of this Society it shall be necessary to be proposed in writing by two members, and at a subsequent meeting to be recommended by the Council, and to receive a majority of the ballots of the members present.

\section{II.}

Each new member shall pay to the Society an initiation fee of five dollars.

\section{III.}

The annual dues shall be five dollars, payable on the Ist of January. Each new member shall pay in proportion to the unexpired fraction of the year at the time of his election.

IV.

Should the annual dues of any member remain unpaid beyond a reasonable time, the Council shall remove his name from the list of members, after due notice.

\section{V.}

The Regular Meetings shall be held at 3 P.M. on the last Saturday of January, February, March, April, May, October and November, unless otherwise ordered by the Council. The place of meeting shall be designated by the Council. The Annual Meeting shall be held on such day as the Council may decide upon between the 26th and 3 Ist of December inclusive.

VI.

Notice of the time and place of each meeting shall be sent by the Secretary to such members of the Society as may request it. 
VII.

The order of business at the meetings of the Society shall be as follows:

I. Reading of the minutes.

2. Recommendations and reports.

3. Elections.

4. Miscellaneous business.

5. Presentation and discussion of papers previously announced.

6. Any other scientiflc communications.

VIII.

No question relative to administration shall be considered at any meeting except the Annual Meeting, without the recommendation of the Council.

IX.

I. The President shall convoke the Council whenever the affairs of the Society require it.

2. A request in writing from two members of the Council shall render the convocation obligatory.

$\mathrm{X}$.

I. The Society shall publish a periodical of a critical and historical nature, called the BULLETIN OF THF AMERICAN MATHematical SocietTy.

2. The Committee of Publication may associate with itself other members of the Society whose editorial assistance it may require.

$\mathrm{XI}$.

It shall be the duty of each President to deliver an address before the Society at the Annual Meeting next succeeding his first election as President of the Society.

XII.

No by-law shall be enacted, amended or suspended, except by a two-thirds vote of the members present at a meeting of the Society, and upon the recommendation of the Council. 